\title{
The Effects of Children's Literature on Preservice Early Childhood Mathematics Teachers' Thinking
}

\author{
Christopher C. Jett \\ University of West Georgia \\ cjett@westga.edu
}

\begin{abstract}
In this article, the author shares an intervention of using children's literature as a pedagogical frame for an undergraduate mathematics content course with early childhood education majors to influence their thinking about mathematics teaching and learning. With this case study of 29 preservice teachers, the author found that literature increased preservice elementary teachers' excitement about mathematics, heightened their self-efficacy in mathematics, and motivated them to design innovative mathematics lessons. Results highlight the continued need for mathematically competent teachers in elementary classroom spaces, and the author advocates for the incorporation of literature as a means to do this work. Finally, the author provides implications for future research and practice with other Scholarship of Teaching and Learning (SoTL)-related projects involving children's literature.
\end{abstract}

Keywords: children's literature, mathematics education, early childhood education

\section{Introduction}

The mathematics taught at the early childhood level is intellectually robust, and prospective elementary teachers must recognize the richness of mathematics at that level (Mathematical Association of America [MAA] \& American Mathematical Society [AMS], 2001). In this manuscript, the terms prospective teachers, early childhood majors, elementary preservice teachers, and students are used interchangeably; these constructs all refer to undergraduate students who are seeking their teaching certification in early childhood education (PreK-5). Notwithstanding, there are prospective teachers who have some deficiencies in mathematics, suffer from mathematics anxiety, or possess low self-confidence in mathematics, and hence should seek to break the cycle of being defeated by mathematics for improved mathematics teaching and learning at the early childhood level.

On the other hand, preservice elementary teachers generally have an affinity toward children's literature (Purdum-Cassidy et al., 2015). In line with this, the National Council of Teachers of Mathematics (NCTM) encourages the use of literature in mathematics as a medium to address mathematics standards in an ingenious fashion (NCTM, 2000). These ideas are echoed in the Common Core State Standards for Mathematics (CCSSM) (National Governors Association Center for Best Practices, Council of Chief State School Officers, 2010). To this end, integrating literature with mathematics is in sync with national efforts to improve mathematics education. Thus, it seems prudent to capitalize on prospective elementary teachers' ties to literature as a mechanism to influence their thinking about mathematics teaching and learning.

The focus of this case study is to share results of a scholarship of teaching and learning (SoTL) mini-grant project-a pedagogical intervention of using children's literature as a didactical framework to influence early childhood education majors' thinking about 
mathematics. In doing so, there are some questions for critical consideration. What sorts of mathematical experiences are needed for early childhood prospective teachers to obtain certification and be deemed capable of delivering effective mathematics instruction in schools? Why do so many prospective elementary teachers have ill feelings, negative experiences, and shallow beliefs concerning mathematics while maintaining an affinity for children's literature? Why, despite many of the current efforts to promote Science, Technology, Engineering, and Mathematics (STEM) education, do certifying bodies continue to license teachers who have disdains for and obvious gaps in their mathematical knowledge systems? And how do teacher educators convince preservice teachers that their future roles as early childhood educators will provide the foundation upon which students' later mathematics trajectories are built?

These questions, among others, have provided the impetus for this SoTL study. Moreover, these questions provide opportunities to reflect more deeply and critically about ways to improve early childhood teacher education in general and engage preservice teachers in the mathematics teaching and learning dynamic in particular. To address these issues, children's literature was used to influence preservice teachers' ideas about mathematics pedagogy through this pedagogical intervention. The following research question was used to drive this study: How might the incorporation of children's literature in a mathematics content course influence preservice early childhood teachers' thinking about mathematics teaching and learning?

This article begins with a discussion of analogous SoTL research studies integrating mathematics and literature with preservice teachers followed by descriptions of the program and this case study's participants. Then, the pedagogical intervention is discussed. After that, the methods and results sections chart with specificity the methodological practices for data collection and the results obtained from collected data. Next, implications for future research and scholarship as well as practice are emphasized as it relates to early childhood education. The author concludes this article by summarizing ideas and posing questions for critical reflection, dialogue, and action among teacher educators who might engage in similar SoTL-related projects.

\section{Related Literature}

There is a growing body of contemporary literature that explores using children's literature in different contexts (see, e.g., Edelman, 2017; Flevares \& Schiff, 2014; LeSage, 2013; Massey, 2015). In this section, some post-secondary research studies with preservice elementary teachers that directly parallel this work are highlighted.

Hillman's (2000) study with 51 preservice teachers in two sections of an elementary mathematics methods course was intended for preservice teachers to design and implement meaningful mathematics instruction with literature connections. Qualitative data sources included copies of lesson plans, field notes from observations, and written reflections from class activities and lessons taught. The findings revealed lessons were designed and then were categorized based on the following three groups: strong link, weak link, or no link. A strong link meant solid connections were made between the mathematical ideas in the literature and the accompanying mathematical activities. A weak link occurred when mathematical connections were minimal or not emphasized when preservice teachers finished reading a book. Lastly, no link represented a mismatch between the mathematics lesson and the mathematics embedded within the literature. Hillman suggested that preservice teachers should be allowed opportunities 
to design mathematics lessons around literature, execute these lessons in real classrooms, and reflect on these experiences to augment the learning process.

In another study, Wilburne and Napoli (2008) examined the beliefs of eight preservice elementary teachers about teaching mathematics through a novel. Data sources included the following: interviews, written responses from focus group questions, reader response notebooks (whereby preservice teachers recorded interdisciplinary connections and made notes for minilessons surrounding the novel), mathematical autobiographies, field notes of the dramatization of the novel, and mathematics lesson plans. Preservice teachers discussed the novel within literature circle groups to share ideas of how to translate theory to practice. Results from the study's data yielded three overarching themes: (1) literature helps motivate preservice teachers to learn mathematics; (2) constructing mathematics lessons around literature helps preservice teachers make sense of mathematics more meaningfully; and (3) teachers need to be more proactive with respect to making mathematical connections to literature. Additionally, the study revealed a significant shift in the preservice teachers' beliefs about, interests in, and benefits of teaching mathematics through literature.

As it relates to pedagogy, Ward (2005) inspired $30 \mathrm{~K}-8$ preservice teachers' future mathematics pedagogy by presenting activities and ideas in an elementary mathematics methods course. She did this by showcasing the unique ways in which mathematics and language skills can develop simultaneously. More specifically, she connected mathematics, social studies, and science as well as mathematics, geography, and mapmaking through children's literature. She also integrated mathematics and poetry. Finally, she required her preservice teachers to author a piece of children's literature to demonstrate their literary ingenuity. Ward advised mathematics teacher educators to equip $\mathrm{K}-8$ preservice teachers with tools, resources, and strategies to effectively integrate literature into mathematics classrooms.

As it stands, the works of Hillman (2000), Wilburne and Napoli (2008), and Ward (2005) provide the backdrop for this SoTL study and can be replicated in teacher education programs across the nation. This SoTL study parallels Hillman's work in that students designed mathematics lessons, implemented them, and reflected on this practice. With regard to Wilburne and Napoli's work, this SoTL study utilizes literature circle teams to explore mathematical ideas. Further, Ward sought to establish connections to other academic disciplines. Ward also advised mathematics teacher educators to provide preservice teachers with resources to teach mathematics through children's literature effectively, and this current SoTL study seeks to achieve these aims. Collectively, their research findings informed this case study, and this SoTL project extends this body of research.

There are other studies that use multicultural children's literature as a context for teaching mathematics (Leonard, Moore, \& Brooks, 2014; Strutchens, 2002) and connect science and mathematics with children's literature (Jewett et al., 2015). In the literature, there are also useful resources for teacher educators who have a desire to infuse mathematics-themed literature in their instructional practices (e.g., Casey, Kersh, \& Young, 2004; Schiro, 1997; Thompson et al., 2008; Ward, 2009; Whitin \& Whitin, 2004) as well as national standards to guide teacher educators regarding the preparation of PreK-12 mathematics teachers (see, Association of Mathematics Teacher Educators, 2017). These works underscore how the study included herein extends existing SoTL in early childhood teacher education, and these works provide worthwhile resources for scholar-practitioners. In what follows, a description of this study is provided. 
Jett

\section{The SoTL Study}

As mentioned previously, the research question to guide this research study was as follows: How might the incorporation of children's literature in a mathematics content course influence preservice early childhood teachers' thinking about mathematics teaching and learning? Below the program and the participants involved in this study are described to further contextualize this case study. Then, specific information about the intervention is provided in light of the mathematics content course.

\section{Program Description and Participants}

The participants for this project consisted of a cohort of 29 early childhood education majors in a traditional teacher preparation program at a university in the southeastern United States: four males and 25 females. These early childhood education majors were seeking an undergraduate degree in Early Childhood Education as well as initial teacher certification (PreK-5). Students' major courses were arranged into four blocks during their junior and senior years. In Blocks IIII, students took a mathematics content course along with other education related courses in addition to completing required practicum hours in elementary schools two days per week. The mathematics course that was used for this study was taken during Block I (i.e., algebraic concepts). This content course was designed to build on students' knowledge bases in the numbers and operations domain and broaden their algebraic conceptualizations and understandings. There are mathematics courses in Block II (i.e., geometric concepts) and Block III (i.e., probability and statistics), and students complete their student teaching internship during Block IV.

\section{Pedagogical Intervention}

Children's literature was employed during this project to influence preservice teachers' thinking about mathematics. As mentioned beforehand, literature (e.g., Adler, 2012; Lichtman, 2008a; Scieszka, 1995; Tang, 2005) was infused in the course design to demonstrate the promise, potential, and impact of this SoTL project (Hutchings, Huber, \& Ciccone, 2011). The entire class community read Lichtman's (2008a) Do the Math \#1: Secrets, Lies, and Algebra. The author facilitated the class discussion for this mathematics-themed literature text and provided learning activities to scaffold and deepen students' understandings in this domain (see Jett, 2015 for an extensive discussion of this work).

In addition, students were placed into literature circle teams and worked on a collaborative book presentation (Daniels, 2002). The students read, extrapolated, and presented several texts including: The Joy of Pi (Blatner, 1999), Do the Math \#2: The Writing on the Wall (Lichtman, 2008b), The Toothpaste Millionaire (Merrill, 2006), Mathematicians Are People, Too: Stories from the Lives of Great Mathematicians (vol. 2) (Reimer \& Reimer, 1995), and selected chapters from The Man Who Counted (Tahan, 1993). Other literature circle texts that have been used in subsequent semesters are included in Table 1; the table also includes recommended mathematics ideas to teach in conjunction with these texts. 
Table 1. Mathematics-Themed Children's Literature

\begin{tabular}{|l|l|l|}
\hline Author & Text & Mathematics Idea(s) \\
\hline Adler & Fractions, Decimals, \& Percents & $\begin{array}{l}\text { Fractions, decimals, and } \\
\text { percents }\end{array}$ \\
\hline Calvert & $\begin{array}{l}\text { Multiplying Menace: The Revenge of } \\
\text { Rumpelstiltskin }\end{array}$ & Multiplication \\
\hline Degross & Donovan's Double Trouble & Mathematics anxiety \\
\hline Dobbs & The Great Divide & Division \\
\hline Duffey & The Math Whiz & Mathematics confidence \\
\hline Franco & $\begin{array}{l}\text { Math Poetry: Linking Math and Literature in a } \\
\text { Fresh Way }\end{array}$ & $\begin{array}{l}\text { Various mathematics } \\
\text { concepts through poetry }\end{array}$ \\
\hline Holub & Zero the Hero & Zero and its properties \\
\hline Hutchins & The Doorbell Rang & Division \\
\hline Kroll & Equal Shmequal & Equal and estimation \\
\hline Leedy & The Great Graph Contest & Graphs \\
\hline Mills & Fractions $=$ Trouble! & Fractions \\
\hline Mills & $7 x$ $=$ Trouble! & Multiplication \\
\hline Murphy & Divide and Ride & Division \\
\hline Murphy & Less Than Zero & Negative numbers \\
\hline Neuschwander & Sir Cumference and the Off-the-Chart Desserts & Graphs \\
\hline Princzes & 100 Hungry Ants & Factors \\
\hline Rockwell & 100 School Days & Counting principles \\
\hline Shaskan & If You Were a Fraction & Fractions \\
\hline Souders & Whole-y Cow!: Fractions Are Fun & Fractions \\
\hline Wing & The Night Before the 100th Day of School & Counting principles \\
\hline
\end{tabular}

All of these texts were selected so preservice elementary teachers could present them through multiple modalities. Further, these texts served as interdisciplinary tools to deepen students' conceptual knowledge base regarding mathematics, engage students in mathematical sense making and reasoning, and build interconnected bridges across different content areas (Ward, 2005; Wilburne \& Napoli, 2008). Moreover, students established connections to the mathematics and shared pedagogical lessons, insights, and ideas for use in their future mathematics teaching (Hillman, 2000).

Anticipation guides and other graphic organizers such as the Know, Want to Learn, Learned (KWL) chart, the Frayer Model, and web diagrams were used in tandem with the literature texts to synthesize mathematical ideas and bolster connections to language and literacy. Mathematical concepts from the literature texts reappeared in the mathematics problem sets, algebraic tasks, and other in-class as well as out of class activities and assessments throughout the semester designed for students to engage in and with the Standards for Mathematical Practice (SMPs) as outlined in the CCSSM (National Governors Association Center for Best Practices, Council of Chief State School Officers, 2010).

All of the learning designs were tied to literature to allow early childhood education majors to explore mathematical ideas via in-depth analysis and propel their mathematics achievement outcomes. Students also completed various activities to improve their precision of mathematical vocabulary and increase the usage of accurate mathematical vocabulary. For Journal of the Scholarship of Teaching and Learning, Vol. 18, No. 1, January 2018. 
example, students kept a Word-A-Day Calendar; students completed vocabulary activities; and students were expected to define and write about mathematics on various assessment tools. The pedagogical goal was not only for preservice teachers to link literature to mathematics but also for them to deeply understand the SMPs, synergistically unpack the standards, and critically address how to implement them in their respective classroom spaces. By designing mathematics learning activities, preservice teachers were provided opportunities to research ideas, pose problems, and author high-level mathematics tasks aligned to their literature texts. These evidence-based SoTL pedagogical aspects foster long-lasting leaning for students as espoused by Hutchings, Huber, and Ciccone (2011). Next, a discussion of the research methods for this project is provided.

\section{Methods}

Case study research "is an empirical inquiry that investigates a contemporary phenomenon (the "case") in depth and within its real-world context, especially when the boundaries between phenomenon and context may not be clearly evident” (Yin, 2013, p. 16). Case study researchers investigate cases for the purpose of explaining, understanding, and making the public aware about the cases (Hays, 2004). Fundamentally, case studies provide solutions and offer analyses of various solutions so that others can adapt these solutions in their own settings. Using the case study research approach, the author engaged in this SoTL project with this specific case-a cohort of 29 early childhood education majors. With this case study, both quantitative and qualitative data collection research methods were employed to understand how the incorporation of literature influenced students' thinking about mathematics teaching and learning.

\section{Data Collection and Analysis}

To collect quantitative data, the author requested for preservice elementary teachers to complete a pre- and post-Likert scale survey consisting of 20 items with the following response codes: $1=$ Strongly Disagree; 2 = Disagree; $3=$ Neutral; 4 = Agree; and $5=$ Strongly Agree. To respect confidentiality, preservice teachers were asked not to include their names on the surveys and were promoted to include a student identification number on it. The survey was adapted from the Attitudes Toward Mathematics Inventory (ATMI) (Tapia \& Marsh, 2004). This attitude survey evaluates engagement with mathematics, and it was employed in this project to examine how literature influences students' thinking about mathematics teaching and learning. Notably, the ATMI has a .97 reliability with college students, and the content validity has been established.

The modified ATMI solicited information about their beliefs and feelings concerning mathematics. In particular, students were questioned about the value of mathematics in everyday life, the satisfaction out of solving a mathematics problem, and having self-confidence in mathematics. Statements were tailored to the specific goals of this research project. Examples included statements pertaining to enjoying reading a storybook about mathematics, infusing literature into the mathematics classroom, and designing mathematics lesson ideas around literature. To view the complete survey administered to students, please see Table 2.

Qualitatively, students submitted a narrative reflection at the end of the semester as reflections make students self-aware of their learning progress and simultaneously provide data for SoTL projects (Hutchings, Huber, \& Ciccone, 2011). In this reflective paper, preservice teachers chronicled their experiences as a mathematics student from early childhood until now, 
discussed how their own mathematical experiences might influence their future mathematics teaching, elaborated on how the incorporation of children's literature assisted with their own mathematics learning, and explained how this mathematics content course has been different from previous mathematics content courses taken. To view the complete assignment details, please see Table 3. After examining the students' reflective narratives, the author coded the qualitative data and placed them in various categories based upon themes (Bogdan \& Biklen, 2007). Samples of students' narratives along with survey results are included in the subsequent results section to substantiate the findings, and pseudonyms are used to maintain anonymity.

\section{Table 2. Survey Instrument for Quantitative Data}

\begin{tabular}{|c|c|c|}
\hline No & STATEMENT & RESPONSE \\
\hline 1. & Mathematics is a very worthwhile and necessary subject. & \\
\hline 2. & $\begin{array}{l}\text { I want to develop my mathematical skills so that I can become an effective } \\
\text { teacher. }\end{array}$ & \\
\hline 3. & I get a great deal of satisfaction out of solving a mathematics problem. & \\
\hline 4. & $\begin{array}{l}\text { I get a great deal of satisfaction out of reading a storybook about } \\
\text { mathematics. }\end{array}$ & \\
\hline 5. & Mathematics is important in everyday life. & \\
\hline 6. & Mathematics is one of the most important subjects for people to study. & \\
\hline 7. & I can think of many ways to teach mathematics in a classroom setting. & \\
\hline 8. & $\begin{array}{l}\text { I can think of many ways that I use mathematics outside a classroom } \\
\text { setting. }\end{array}$ & \\
\hline 9. & Mathematics is one of my most dreaded subjects. & \\
\hline 10. & Studying mathematics makes me feel nervous. & \\
\hline 11. & I expect to do fairly well in any mathematics class I take. & \\
\hline 12. & I am always confused in a mathematics class. & \\
\hline 13. & I am happier in math than in any other class. & \\
\hline 14. & Mathematics is dull and boring. & \\
\hline 15. & I feel a sense of insecurity when attempting mathematics. & \\
\hline 16. & I have a lot of self-confidence when it comes to mathematics. & \\
\hline 17. & I really enjoy mathematics. & \\
\hline 18. & I really enjoy reading. & \\
\hline 19. & I can infuse literature into a mathematics classroom effectively. & \\
\hline 20. & $\begin{array}{l}\text { Designing mathematics lessons around literature helps make mathematics } \\
\text { more meaningful. }\end{array}$ & \\
\hline
\end{tabular}

Journal of the Scholarship of Teaching and Learning, Vol. 18, No. 1, January 2018. 


\section{Table 3. Narrative Reflection Assignment for Qualitative Data}

DIRECTIONS: Please provide honest, critical assessments concerning the questions that you choose to answer. Please answer some of the following prompts:

How has this mathematics course been different from other mathematics courses you have taken?

How have your own experiences as a mathematics student influenced how you will teach mathematics in elementary spaces?

How did the incorporation of literature assist with your mathematics learning and/or algebraic thinking?

How did the cooperative learning activities linked with literature enhance your individual mathematics learning?

What was the most valuable thing you learned in this course (this is not relegated to math)? Explain its significance to you.

\section{Results}

For the quantitative data, the mean pre-score and the mean post-score were calculated for each survey statement. Also, the mean difference between the pre- and post-scores and the standard deviation were calculated. Please see Table 4 to view the survey data's calculations in a systematic fashion. Pre- and post-survey data were analyzed to ascertain whether or not gains were noted regarding preservice teachers' ideas about mathematics teaching and learning with respect to literature and their experiences learning mathematics in this fashion. As mentioned earlier, Table 4 includes results pre- and post-means as well as pre- and post-standard deviations (SD) for all pre- and post-items. Addedly, a two-tailed t-test was conducted to determine the statistical significance of the differences between the pre-post mean scores. The significance test yielded a p-value of 0.011522. Therefore, it was determined that the increases were significant regarding the pedagogical goals of this SoTL intervention.

Conversely, some statements from the survey data yielded a negative response. In particular, Statement 11 had the largest adverse effect. The statement read: "I expect to do fairly well in any mathematics class I take.” Perhaps preservice teachers thought they would perform exceptionally well in this mathematics content course given the focus on the pedagogical intervention. Some students were frustrated, however, that they did not perform well on various mathematics assessment items.

As a whole, preservice teachers' ideas about mathematics and literature were greatly influenced through their enrollment in the mathematics content course in general and their engagement with the SoTL intervention in particular. Coupling this survey data with the qualitative data yielded three overarching themes that emerged from the analysis of the data. These themes included: (1) increased excitement about mathematics because of literature, (2) heightened self-efficacy in mathematics, and (3) motivated early childhood education majors to be innovative regarding teaching mathematics. These themes are discussed taking into account supporting data. 
Table 4. Survey Data

\begin{tabular}{|c|c|c|c|c|c|}
\hline Statement & Pre-Mean & Post-Mean & Difference & Pre-SD & Post-SD \\
\hline Statement \#1 & 4.36 & 4.32 & -0.04 & 0.70 & 0.79 \\
\hline Statement \#2 & 4.72 & 4.80 & 0.08 & 0.45 & 0.40 \\
\hline Statement \#3 & 3.48 & 3.88 & 0.40 & 1.36 & 1.11 \\
\hline Statement \#4 & 2.76 & 3.48 & 0.72 & 0.91 & 1.06 \\
\hline Statement \#5 & 4.32 & 4.40 & 0.08 & 0.79 & 0.69 \\
\hline Statement \#6 & 4.20 & 4.36 & 0.16 & 0.75 & 0.79 \\
\hline Statement \#7 & 3.44 & 3.96 & 0.52 & 1.06 & 0.87 \\
\hline Statement \#8 & 4.08 & 4.32 & 0.24 & 0.89 & 0.68 \\
\hline Statement \#9 & 3.28 & 3.48 & 0.20 & 1.56 & 1.60 \\
\hline Statement \#10 & 3.52 & 3.40 & -0.12 & 1.55 & 1.47 \\
\hline Statement \#11 & 4.04 & 3.56 & -0.48 & 0.77 & 1.10 \\
\hline Statement \#12 & 2.56 & 2.68 & 0.12 & 1.20 & 1.32 \\
\hline Statement \#13 & 2.48 & 2.60 & 0.12 & 1.24 & 1.26 \\
\hline Statement \#14 & 2.20 & 2.32 & 0.12 & 1.06 & 1.19 \\
\hline Statement \#15 & 3.04 & 2.96 & -0.08 & 1.46 & 1.40 \\
\hline Statement \#16 & 2.56 & 3.04 & 0.48 & 1.30 & 1.46 \\
\hline Statement \#17 & 3.16 & 3.16 & 0.00 & 1.25 & 1.32 \\
\hline Statement \#18 & 3.80 & 4.00 & 0.20 & 1.13 & 1.02 \\
\hline Statement \#19 & 3.24 & 4.04 & 0.80 & 0.91 & 0.87 \\
\hline Statement \#20 & 3.76 & 4.36 & 0.60 & 0.99 & 0.74 \\
\hline
\end{tabular}

Theme 1: Increased Mathematics Excitement because of Literature

Preservice teachers expressed the mathematics-themed literature caused them to exhibit more enthusiasm about mathematics. Their comments echoed the findings in Wilburne and Napoli's (2008) study. The gains in response to statement two from the survey data also support these ideas (Statement 2: I want to develop my mathematical skills so that I can become an effective teacher). In this respect, the integration of mathematics and literature yielded a unique excitement about the mathematics teaching and learning process. One preservice teacher declared:

I hate math, luckily this Algebra for Teachers course is not your typical math class. This course takes differentiation to a new level, through the use of not only math, but literature, articles, and if we're lucky pizza. In my past math classes going all the way back to elementary school, I always dreaded them...by using literature and hands-on examples, students like me can begin to enjoy and comprehend math. (Preservice Teacher Amy)

Amy had some struggles with mathematics during her earlier schooling experiences. She paid particular attention to the intervention as well as differentiation. Along with other students who mentioned they were learning about differentiation in their education courses, she cited this course as one whereby she could recognize differentiated instruction. She also mentioned pizza in her reflection paper referring to a lesson in which one literature circle group brought in real pizzas to assist with teaching and understanding fraction concepts. One of the literature circle group members worked as an assistant manager of a nearby pizzeria. The pizza overshadowed Journal of the Scholarship of Teaching and Learning, Vol. 18, No. 1, January 2018. 
the mathematics lesson because the preservice teachers were more excited about the free lunch. However, the teachable moment provided an opportunity to learn about mathematics as well as staying focused and taking care to stress the mathematics connections with such an exciting learning activity.

Overall, the preservice teachers were excited about mathematics because of literature. They also expressed presenting their literature circle text to the class was exhilarating. One literature circle team dressed up as prisoners and guards to bring to life how Beremiz solved the problem of halving the years Sanadik was to spend in the great prison of Baghdad (see, Tahan, 1993). Another literature circle group wrote a Pi Day rap and made a mathematics video of their rap to accompany their presentation of Blatner's (1999) text. As such, their literature circle presentations corroborated their excitement about this SoTL project.

\section{Theme 2: Heightened Self-Efficacy in Mathematics}

Students expressed heightened levels of self-efficacy in mathematics. In other words, the learning experience allowed them to see themselves more as mathematically capable thinkers. As the results from the third statement in Table 4 indicate, gains were made concerning students' self-confidence about mathematics (Statement 3: I get a great deal of satisfaction out of solving a mathematics problem). This self-efficacy paradigm was generated/shifted despite several difficulties with mathematics during many of their previous schooling experiences as shared in their reflective narratives.

Having challenges with mathematics prior to this course was a persistent theme throughout the reflective narratives. Narratives from two students who professed they struggled with mathematics for many years are shared. One student disclosed:

Before beginning this course, I was not as confident about my math abilities and feared math as an obstacle that I never thought I could overcome. Through great teaching and a willingness to learn more about a subject that I have in the past struggled with, I feel as though I am confident to introduce math as an adventure that should never be seen as complicated or fearful. (Preservice Teacher Becky)

It is important to note that Becky communicated her fear of mathematics at the beginning of the semester after one of our initial class meetings. Through this SoTL intervention, however, she exhibited heightened self-efficacy concerning her mathematical abilities. This student not only shared thoughts about her self-efficacy in mathematics, but she also transferred these skills to her ability to perform this work as a future classroom teacher.

Another student who struggled in mathematics conveyed:

I really don't remember when I started hating math. I guess it was ingrained in me from the start. I realize now at the age of 31 that not liking math was all from my past teachers. I never once had a teacher encourage me or tell me that I was good at math until I had [the author].... With [the author] encouraging me, telling me I could do the problem, and making me go to the board to work out a problem with the help of others, I started to develop confidence in math. (Preservice Teacher Christina)

Christina had many struggles with mathematics and shared she enrolled in College Algebra five times before successfully completing the course. Actually, her struggles with College Algebra coupled with her remedial mathematics course pattern taking at the community college prior to her enrollment at the university and other responsibilities resulted in her being a non-traditional undergraduate student. Her persistence in the subject is remarkable, and she noted this SoTL 
intervention helped her self-confidence in mathematics. Moreover, she credited the pedagogical style of the course as being instrumental in her development of mathematical confidence. Her comments also touch on some of the elements in theme three, which is presented below.

\section{Theme 3: Motivated Early Childhood Education Majors to Design Innovative Mathematics Lessons}

In this mathematics content course, literature was used as a differentiation tool that spanned across multiple intelligences while keeping mathematical ideas at the forefront. The MAA in conjunction with the AMS (MAA \& AMS, 2001) declare that: “In order to support children's learning in this realm, teachers first must do this work for themselves” (p. 20). More precisely, preservice teachers must first experience the effects of mathematics-themed children's literature as an empowering intervention if they will later do this innovative work in their own classroom spaces. Consequently, my instructional practices modeled literature integration via novel strategies, tools, and techniques for the students. As they observed my instructional practices through the lenses of student and prospective teacher, the preservice teachers extended their efforts to be innovative in their own teaching. One preservice teacher shared:

This [the incorporation of literature] could honestly be the missing piece of the puzzle when it comes to children's lack of excitement about mathematics. Integrating these two subjects is something I plan to do on a daily basis within my classroom. Through the integration of literature and mathematics, I hope to rid children of their fears about mathematical concepts. (Preservice Teacher Demetria)

Demetria articulated her viewpoints in this domain. She championed literature as "the missing piece of the puzzle” that represents elementary students' mathematical experiences. Her narrative relies on an assumption that children lack excitement about mathematics or have fears about mathematical concepts. This assertion could be because of her own perceptions of learning mathematics as a child. Such statements and ideological orientations about mathematics must be challenged in early childhood teacher education given that young children are generally excited about mathematics learning. On the contrary, her narrative supports the theme of making improved efforts to be innovative in her mathematics instruction through children's literature.

Through the analysis of preservice teachers' surveys and reflections, data revealed students exhibited increased excitement about mathematics, heightened self-efficacy in mathematics, and improved efforts to be innovative practitioners. As already mentioned, Table 4 portrays the quantitative changes that occurred in students' thinking related to each of the three themes that emerged from the analysis of the qualitative data. These findings answered the research question: How might the incorporation of children's literature in a mathematics content course influence preservice early childhood teachers' thinking about mathematics teaching and learning? With regard to the research question, the data suggest literature increased their excitement about mathematics, heightened their self-efficacy in mathematics, and motivated them to design innovative mathematics lessons. In the next section, implications for future work are shared. 


\section{Implications}

\section{Research and Scholarship}

Based on the findings from this case study, this SoTL project lends itself to several implications for future research and scholarship. Through this study, it was found that prospective teachers' intellectual and creative schemas were magnified through children's literature. Therefore, more SoTL projects are needed to measure students' self-efficacy as they explore and design pedagogical innovations. Future inquiries should also investigate how early childhood preservice teachers' mathematics dispositions are influenced as a result of a pedagogical intervention such as this one, especially given the mathematically deficient labels often ascribed to prospective elementary teachers.

Additionally, future studies are needed to more fully understand how mathematics pedagogical and content knowledge are developed with respect to children's literature. This work goes beyond incorporating reading into the content areas; instead, this intervention should foster rigorous mathematics instruction anchored in students' experiences (Gay, 2010). Literature can make mathematics teaching and learning more meaningful (Jett, 2014; Thompson et al., 2008; Ward; 2009; Zambo, 2005). Consequently, future studies should be conducted with preservice teachers to explicate how mathematical ideas are solidified through children's literature and even extend these ideas through problem writing (Barlow \& Drake, 2008). Researchers could utilize the Mathematics and Children's Literature Brief Inventory to explore how teachers' ideological orientations inform their use of children's literature during the mathematics teaching and learning process (Cotti \& Schiro, 2004). These studies should be replicated or modified in teacher preparation programs across the nation to provide scholars with a more comprehensive understanding of this work. For example, a replication study could be done with preservice teachers at Historically Black Colleges and Universities (HBCUs) and other Minority Serving Institutions (MSIs) given their unique mission to provide equitable mathematics learning opportunities for culturally diverse students to ascertain how findings would be similar or dissimilar.

Finally, future research should explore the use of children's literature to expose students to STEM education in early childhood classroom spaces (see, Vasquez, Sneider, \& Comer, 2013). Because of the unique role of mathematics in STEM, children's literature could provide more access to teaching and learning about STEM possibilities. In this vein, a longitudinal research study whereby early childhood students' STEM trajectories are charted throughout their schooling experiences using different SoTL interventions such as the literature one to propel students in this realm would be beneficial for the field. The goal should not necessarily be to produce more STEM graduates. Rather, the goal should be to produce STEM literate citizens who can use mathematical and literature principles for the empowerment of self, community, and the world. Essentially, future research studies such as the aforementioned ones could offer much to advance the SoTL canon.

\section{Practice}

In conducting this study, the author educed that infusing children's literature in the mathematics classroom has many implications for practice. The dominant discourse suggests some prospective elementary teachers have mathematical deficiencies, and national documents in 
mathematics education state teachers' mathematics content knowledge is related to students' mathematical performance (AMS \& MAA, 2012; MAA \& AMS, 2001; NCTM, 2000). With this case study, many of the preservice teachers initially had a sense of disillusionment and a lack of enthusiasm for mathematics. As a result, one implication from this study's findings is that it is important for early childhood teacher education scholars to model excitement and heightened self-efficacy in mathematics with preservice teachers.

Next, a practical implication is for teacher educators to use children's literature as a vehicle to engage preservice and in-service teachers alike in the mathematics teaching and learning dynamic. As the research suggests, exposing them to literature alone in teacher education programs or professional development sessions is not sufficient-teachers must extend the work embedded within literature texts to author mathematics tasks and learning activities, create reform-oriented questions (Purdum-Cassidy et al., 2015), infuse advocacy letter writing in concert with the text's learning goals (Massengale, Childers-McKee, \& Benavides, 2014), and develop mathematics writing prompts responsive to the needs of their students. With this case study, children's literature prompted the early childhood education majors to be creative and innovative in their mathematics lesson designs, so teacher educators should capitalize off of literature's creative schemas to extend this work in unique ways.

Teacher educators should also devise support mechanisms for preservice teachers to learn various ways to incorporate children's literature into mathematics lessons (Rogers et al., 2015). As Hillman (2000) recommends, solid connections must be made between the mathematical concepts and the accompanying mathematics learning designs to promote mathematics achievement outcomes among students. These connections should be extended to other academic disciplines to show the utility of children's literature to other content areas (see, e.g., Maples \& Taylor, 2013; Vasquez, Sneider, \& Comer, 2013). All in all, early childhood teacher educators should systematically utilize children's literature to positively influence students' pedagogical thinking and buttress their mathematics learning outcomes.

\section{Conclusion}

As the data from this case study revealed, children's literature increased preservice teachers' excitement about mathematics, heightened their self-efficacy in mathematics, and motivated them to be innovative with their mathematics lesson designs. Wu (2011) argues: "Because teachers also have to answer questions from students, some of which can be quite profound, their knowledge of what they teach must go beyond the minimal level” (pp. xv-xvi). Relatedly, preservice teachers' knowledge base must deepen if we expect them to deliver effective instruction that will weave academic disciplines such as mathematics and literature together in innovative ways. Considering that early childhood educators' roles lend themselves to integrating academic disciplines and establishing a culture where students are positioned as thinkers, doers, and contributors to the academic enterprise, this work is critically important at this developmental juncture in children's lives.

Also, this SoTL project is significant because reform efforts in both early childhood and mathematics education encourage the incorporation of evidence-based instructional practices such as teaching mathematics through literature (National Association for the Education of Young Children [NAEYC] \& NCTM, 2010). Previous research supports that teachers' beliefs about early childhood mathematics instruction influence their pedagogical practices (Brown, 
2005). Therefore, SoTL efforts and studies to influence prospective early childhood educators' thinking and belief systems regarding mathematics pedagogy must be employed.

To challenge readers' epistemological ideas surrounding mathematically competent teachers at the early childhood level, the following questions could serve as discussion prompts for the teacher education community writ large: What are the present teacher education goals for early childhood education majors? How might existing SoTL studies help to achieve these goals? How might children's literature inform these goals? What types of curricula, pedagogical approaches, and theoretical orientations are effective in helping prospective elementary school teachers gain mathematics conceptual, pedagogical, and cultural knowledge needed for effective mathematics teaching and learning? And how might innovative SoTL practices work in line with these ideas?

In closing, the research literature indicates there is a need for skilled, effective teachers not only for the sustainment of the mathematical enterprise, but also to make certain that our children are provided with the high-quality teachers, rigorous and equitable mathematics instruction, and culturally responsive curricula and evaluative tools needed for this time (Delpit, 2012; Gay, 2010; White et al., 2016). Children's literature is a vehicle to achieve this goal. Literature helps to foster positive dispositions about mathematical activity as found through this case study and previous SoTL work (Hillman, 2000; Ward, 2005; Wilburne \& Napoli, 2008). The author beseeches teacher education pedagogues to act and jointly engage in SoTL projects with preservice teachers for the sake of the classrooms, families, and communities they will serve.

\section{Acknowledgements}

This research project was supported by an intramural University of West Georgia Institutional STEM Excellence (UWise) faculty mini-grant, and the author would like to thank the Georgia Board of Regents STEM Initiative for their support of this project. The author would also like to thank Dr. Erika C. Bullock for her feedback on an earlier draft of this manuscript.

\section{References}

American Mathematical Society, \& Mathematical Association of America. (2012). The mathematical education of teachers II. Providence, RI: American Mathematical Society.

Association of Mathematics Teacher Educators. (2017). Standards for preparing teachers of mathematics. Available online at amte.net/standards.

Barlow, A. T., \& Drake, J. M. (2008). Division by a fraction: Assessing understanding through problem writing. Mathematics Teaching in the Middle School, 13(6), 326-332.

Bogdan, R. C., \& Biklen, S. K. (2007). Qualitative research for education (5th ed.). Boston, MA: Allyn \& Bacon.

Brown, E. T. (2005). The influence of teachers' efficacy and beliefs regarding mathematics instruction in the early childhood classroom. Journal of Early Childhood Teacher Education, 26(3), 239-257. https://doi.org/10.1080/10901020500369811 
Jett

Casey, B., Kersh, J. E., \& Young, J. M. (2004). Storytelling sagas: An effective medium for teaching early childhood mathematics. Early Childhood Research Quarterly, 19(1), 167-172. https://doi.org/10.1016/j.ecresq.2004.01.011

Cotti, R., \& Schiro, M. (2004). Connecting teacher beliefs to the use of children's literature in the teaching of mathematics. Journal of Mathematics Teacher Education, 7(4), 329-356. https://doi.org/10.1007/s10857-004-1787-z

Daniels, H. (2002). Literature circles: Voice and choice in book clubs and reading groups (2nd ed.). Portland, ME: Stenhouse.

Delpit, L. (2012). "Multiplication is for White people”: Raising expectations of other people's children. New York, NY: The New Press.

Edelman, J. (2017). How preservice teachers use children's literature to teach mathematical concepts: Focus on mathematical knowledge for teaching. International Electronic Journal of Elementary Education, 9(4), 741-752.

Flevares, L. M., \& Schiff, J. R. (2014). Learning mathematics in two dimensions: A review and look ahead at teaching and learning early childhood mathematics with children's literature. Frontiers in Psychology, 5, Article 459, 1-12. https://doi.org/10.3389/fpsyg.2014.00854

Gay, G. (2010). Culturally responsive teaching (2nd ed.). New York, NY: Teachers College Press.

Hays, P. A. (2004). Case study research. In K. deMarrais \& S. D. Lapan (Eds.), Foundations for research: Methods of inquiry in education and the social sciences (pp. 217-234). Mahwah, NJ: Lawrence Erlbaum Associates.

Hillman, S. L. (2000). Learning to teach mathematics with literature connections. Paper presented at the Twenty-second annual meeting of the North American Chapter of The International Group for the Psychology of Mathematics Education. Tucson, AZ, October 7-10.

Hutchings, P., Huber, M. T., \& Ciccone, A. (2011). The scholarship of teaching and learning reconsidered: Institutional integration and impact. San Francisco, CA: Jossey-Bass.

Jett, C. C. (2014). Using mathematics literature with prospective secondary mathematics teachers. Journal of Mathematics Education at Teachers College, 5(2), 49-53.

Jett, C. C. (2015). Secret, lies, and algebra: Using a novel to explore mathematics concepts. Voices from the Middle, 22(3), 33-37.

Jewett, P., Johnson, D., Lowery, R. M., \& Stiles, J. W. (2015). Connecting science and math concepts with children's and young adult literature in a CCSS world. Journal of Children's Literature, 41(1), 44-47. 
Leonard, J., Moore, C. M., \& Brooks, W. (2014). Multicultural children’s literature as a context for teaching mathematics for cultural relevance in urban schools. The Urban Review, 26(3), 325-348. https://doi.org/10.1007/s11256-013-0264-3

LeSage, A. C. (2013). Don't count on the quality of children's counting books. Paper presented at the 57th International Council on Education for Teaching (ICET) World Assembly, 489-496. Bangkok, Thailand.

Maples, J. N., \& Taylor, M. V. (2013). Writing children’s books in sociology class: An innovative approach to teaching social problems to undergraduate students. Interdisciplinary Journal of Teaching and Learning in Higher Education, 25(3), 358-368.

Massengale, K., Childers-McKee, C., \& Benavides, A. (2014). Exploration of undergraduate preservice teachers' experiences learning advocacy: A mixed-methods study. Journal of the Scholarship of Teaching and Learning, 14(3), 75-92. https://doi.org/10.14434/josotl.v14i3.5071

Massey, S. R. (2015). The multidimensionality of children's picture books for upper grades. English Journal, 104(5), 45-58.

Mathematical Association of America, \& American Mathematical Society. (2001). The mathematical education of teachers: Part I. Providence, RI: American Mathematical Society.

National Association for the Education of Young Children, \& National Council of Teachers of Mathematics. (2010). Early childhood mathematics: Promoting good beginnings. Available online at https://www.naeyc.org/files/naeyc/file/positions/psmath.pdf.

National Council of Teachers of Mathematics. (2000). Principles and standards for school mathematics. Reston, VA: National Council of Teachers of Mathematics.

National Governors Association Center for Best Practices, Council of Chief State School Officers. (2010). Common Core State Standards. Washington, DC: National Governors Association for Best Practices, Council of Chief State School Officers.

Purdum-Cassidy, B., Nesmith, S., Meyer, R. D., \& Cooper, S. (2015). What are they asking? An analysis of the questions planned by prospective teachers when integrating literature in mathematics. Journal of Mathematics Teacher Education, 18(1), 79-99. https://doi.org/10.1007/s10857-014-9274-7

Rogers, R. M., Cooper, S., Nesmith, S. M., \& Purdum-Cassidy, B. (2015). Ways that preservice teachers integrate children's literature into mathematics lessons. The Teacher Educator, 50(3), 170-186. https://doi.org/10.1080/08878730.2015.1038493

Schiro, M. (1997). Integrating children's literature and mathematics in the classroom: Children as meaning makers, problem solvers, and literary critics. New York, NY: Teachers College Press. 
Jett

Strutchens, M. E. (2002). Multicultural literature as a context for problem solving: Children and parents learning together. Teaching Children Mathematics, 8(8), 448-454.

Tapia, M., \& Marsh, G. E. (2004). An instrument to measure mathematics attitudes. Academic Exchange Quarterly, 8(2), 16-21.

Thompson, D. R., Kersaint, G., Richards, J. C., Hunsader, P. D., \& Rubenstein, R. N. (2008). Mathematical literacy: Helping students make meaning in the middle grades. Portsmouth, NH: Heinemann.

Vasquez, J. A., Sneider, C., \& Comer, M. (2013). STEM lesson essentials grades 3-8:

Integrating science, technology, engineering and mathematics. Portsmouth, NH: Heinemann.

Ward, R. A. (2005). Using literature to inspire K-8 preservice teachers' future mathematics pedagogy. The Reading Teacher, 59(2), 132-143. https://doi.org/10.1598/RT.59.2.3

Ward, R. A. (2009). Literature-based activities for integrating mathematics with other content areas. Boston, MA: Pearson.

White, D. Y., DuCloux, K. K., Carreras-Jusino, A. M., González, D. A., \& Keels, K. (2016). Preparing preservice teachers for diverse mathematics classrooms through a cultural awareness unit. Mathematics Teacher Educator, 4(2), 164-187.

https://doi.org/10.5951/mathteaceduc.4.2.0164

Whitin, D. J., \& Whitin, P. E. (2004). New visions for linking literature and mathematics. Urbana, IL: National Council of Teachers of English.

Wilburne, J., \& Napoli, M. (2008). Connecting mathematics and literature: An analysis of preservice elementary teachers' changing beliefs and knowledge. Issues in the Undergraduate Mathematics Preparation of School Teachers (IUMPST): The Journal 2 (Pedagogy), September. Available online at www.k-12prep.math.ttu.edu.

Wu, H-H. (2011). Understanding numbers in elementary school mathematics. Providence, RI: American Mathematical Society.

Yin, R. K. (2013). Case study research: Design and methods (5th ed.). Thousand Oaks, CA: Sage.

Zambo, R. (2005). The power of two: Linking mathematics and literature. Mathematics Teaching in the Middle School, 10(8), 394-399.

\section{Children's Literature References}

Adler, D. (2011). Fractions, decimals, \& percents. New York, NY: Holiday House.

Adler, D. (2012). Mystery math: A first book of algebra. New York, NY: Holiday House. 
Blatner, D. (1999). The joy of pi. New York, NY: Walker \& Co.

Calvert, P. (2006). Multiplying menace: The revenge of Rumpelstiltskin. Watertown, MA:

Charlesbridge.

DeGross, M. (2007). Donovan’s double trouble. New York, NY. Amistad.

Dobbs, D. A. (2005). The great divide. Somerville, MA: Candlewick Press.

Duffey, B. (1997). The math whiz. New York, NY: Penguin Group.

Franco, B. (2006). Math poetry: Linking math and literature in a fresh way. Culver City, CA: Good Year Books.

Holub, J. (2008). Zero the hero. New York, NY: KO Kids Books.

Hutchins, P. (1989). The doorbell rang. New York, NY: Greenwillow.

Kroll, V. (2005). Equal shmequal. Watertown, MA: Charlesbridge.

Leedy, L. (2006). The great graph contest. New York, NY: Holiday House.

Lichtman, W. (2008a). Do the math: Secrets, lies, and algebra. New York, NY: Greenwillow Books.

Lichtman, W. (2008b). The writing on the wall. New York, NY: Greenwillow Books.

Merrill, J. (2006). The toothpaste millionaire. Boston, MA: Houghton Mifflin.

Mills, C. (2004). 7 × 9 = Trouble! New York, NY: Square Fish.

Mills, C. (2012). Fractions = Trouble! New York, NY: Square Fish.

Murphy, S. (1997). Divide and ride. New York, NY: HarperCollins.

Murphy, S. (2003). Less than zero. New York, NY: HarperCollins.

Neuschwander, C. (2013). Sir cumference and the off-the-chart desserts. Watertown, MA:

Charlesbridge.

Princzes, E. (1993). 100 hungry ants. Boston, MA: Houghton Mifflin.

Reimer, L. \& Reimer, W. (1995). Mathematicians are people, too: Stories from the lives of great mathematicians (Vol. 2). Parsippany, NJ: Dale Seymour. 
Rockwell, A. (2004). 100 school days. New York, NY: HarperCollins.

Scieszka, J. (1995). Math curse. New York, NY: Viking Juvenile.

Shaskan, T. S. (2008). If you were a fraction. North Mankato, MN: Picture Window Books.

Souders, T. (2010). Whole-y cow!: Fractions are fun. Ann Arbor, MI: Sleeping Bear Press.

Tahan, M. (1993). The man who counted. New York, NY: W. W. Norton.

Tang, G. (2005). Math for all seasons. New York, NY: Scholastic.

Wing, N. (2005). The night before the 100th day of school. New York, NY: Grosset \& Dunlap. 